\title{
Analisis Kebutuhan Bahan Ajar Berbasis Literasi Digital Nilai-Nilai Kearifan Lokal pada Tradisi Saprahan di Pontianak
}

\author{
Astrini Eka Putri \\ Universitas Tanjungpura, Pontianak, Indonesia \\ astriniekap@fkip.untan.ac.id
}

\begin{tabular}{ccc}
\hline Received & Accepted & Published \\
$27 / 01 / 2020$ & $16 / 06 / 2020$ & $30 / 06 / 2020$ \\
\hline
\end{tabular}

\begin{abstract}
The research is one of the basis for the development of the teaching material for the purpose well aware of needs in the field surrounding the teaching material in order to produce an effective teaching materials and good. Value of local wisdom that can be raised in the development of teaching material that is in West Kalimantan is Saprahan tradition. Methods of research was a qualitative descriptive. Based on the results of research conducted at some schools, the need teaching materials based local history that it is so very high. This led researchers to make teaching material based digital literation for teaching materials values of local wisdom on Saprahan tradition at SMA/SMK.
\end{abstract}

Keywords: teaching history materials, digital literacy, values of local wisdom on tradition saprahan

\begin{abstract}
Abstrak Penelitian ini merupakan salah satu dasar dalam pengembangan bahan ajar dengan tujuan mengetahui kebutuhan di lapangan seputar bahan ajar agar dapat menghasilkan bahan ajar yang efektif dan baik. Nilai-nilai kearifan lokal yang dapat diangkat dalam pengembangan bahan ajar ini adalah salah satunya kearifan lokal yang terdapat di Kalimantan Barat salah satunya adalah Tradisi Saprahan. Metode yang digunakan dalam penelitian ini adalah metode kualitatif deskriptif. Berdasarkan hasil penelitian yang dilakukan pada beberapa sekolah sampel mengenai kebutuhan akan bahan ajar berbasis sejarah lokal, didapatkan fakta bahwa memang selama ini kebutuhan bahan ajar berbasis sejarah lokal sangat tinggi. Hal ini mendorong peneliti untuk membuat bahan ajar berbasis literasi digital nilai-nilai kearifan lokal pada Tradisi Saprahan sebagai solusi atas minimnya bahan ajar sejarah di sekolah-sekolah setingkat SMA/ SMK.
\end{abstract}

Kata kunci: Bahan Ajar Sejarah, Literasi Digital, Nilai-Nilai Kearifan Lokal pada Tradisi Saprahan. 


\section{PENDAHULUAN}

Pendidikan dan kebudayaan adalah dua hal yang tidak dapat dipisahkan. Kebudayaan suatu masyarakat akan mempengaruhi proses pembentukkan kepribadian seorang individu dalam pendidikan, konsep ini tidak hanya di identifikasikan sebagai kegiatan pembelajaran di sekolah akan tetapi juga proses pembudayaan dalam keluarga dan masyarakat. Adanya pendidikan yang mengintegrasikan nilai-nilai budaya sangatlah diperlukan. Integrasi keberagaman budaya dalam pendidikan merupakan aspek penting untuk mencapai tujuan pendidikan, sebagaimana menurut Dewantara (1977:344), “Pendidikan adalah salah satu usaha memberikan segala nilai-nilai kebatinan yang ada dalam hidup rakyat yang berkebudayaan, kepada tiap-tiap generasi muda, tidak hanya berupa pemeliharaan akan tetapi juga dengan maksud memajukan serta mengembangkan kebudayaan menuju kearah keluhuran hidup kemanusiaan".

Pada pembelajaran sejarah banyak menyangkut pembahasan budaya, akan tetappi pembahasan tersebut hanya sebatas materi yang dari tahun-ketahun topiknya tidak berganti. Seharusnya , materi atau bahan ajar bisa dikembangkan lagi dengan topik baru misalnya sejarah lokal, budaya, dan lain-lain. Hal ini bisa dijadikan sebagai salah satu cara untuk melestarikan budaya serta meningkatkan rasa percaya diri siswa untuk memiliki karakternya sebagai bangsa Indonesia.

Globalisasi membawa perubahan bangsa dan negara di penjuru dunia, dengan arti globalisasi sebagai proses saling berhubungan secara global serta individu. Pergantian nilai-nilai dan informasi dari satu negara ke negara lainnya berlangsung secara cepat. Namun pergantian ini memberikan dampak dan dinamika dalam berbagai bidang. Globalisasi memberika berbagai dampak "imperiaisme kultural" dan "homogenitas budaya" dengan melahirkan budaya baru atau campuran. Hal ini menjadi tantangan baru bagi semua pihak dalam suatu bangsa untuk mencari pegangan hidup dan mempertahankan jati diri bangsa yaitu bangsa Indonesia sebagai negara penuh keberagaman budaya dengan khasanah nilai yang tinggo. Oleh karena itu, salah satu instansi yang harus berperan aktif dalam menghadapi tantangan tersebut adalah lembaga pendidikan yang diharapkan ikut berpartisipasi dalam menangani masalah pada abad modernisme ini.

Salah satu cara alternatif untuk mencapai tujuan pendidikan Indonesia dengan melawan dampak negatif dari globalisasi adalah dengan pengembangan bahan ajar berbasis nilai-nilai karakter berdasarkan nilai-nilai kearifan lokal. Pengembangan bahan ajar berbasis nilai -nilai kearifan lokal ini bisa dimasukkan dalam berbagai mata pelajaran. Bahan ajar berbasis nilai-nilai kearifan lokal ini dirasa perlu karena berkaitan dengan nilai-nilai karakter yang merupakan komponen yang dirancang untuk peserta didik guna membentuknya menjadi manusia yang memiliki kepribadian, watak, sikap, dan jati diri yang baik. 
Bahan ajar merupakan bentuk bahan yang telah disesuaikan dengan standar kompetensi atau kompetensi inti. Seperti yang dikemukakan oleh Hamid (2010:212), bahan ajar merupakan materi pembelajaran yang secara garis besar terdiri dari pengetahuan, keterampilan, dan sikap yang harus dipelajari siswa dalam rangka mencapai standar kompetensi yang telah ditentukan. Melalui bahan ajar siswa diantarkan kepada tujuan pengajaran. Menurut Opara dan Oguzor (2011:66) sumber bahan ajar bisa berupa visual maupun audiovisual yang tersedia dan diterapkan serta diintegrasikan kedalam suatu proses belajar mengajar yang sistematis sehingga membuat kegiatan pembelajaran menjadi efektif dan efesien.

Menurut Richards (2001:275) mengkategorikan tiga kelompok bahan ajar antara lain: (1) bahan cetak (printed material) seperti buku teks, buku kerja/latihan dan lembar kerja/ kumpulan bacaan; (2) bahan yang bukan cetakan (non-printed material) seperti kaset (audio material), video atau materi ajar yang berbasis komputer; dan (3) aunthentic and created teaching material, yaitu materi ajar yang berupa sumber-sumber yang berkaitan dengan kehidupan nyatanya, baik dalam bentuk cetakan maupun non-cetakan, misalnya dari majalah,surat kabar, brosur, dan sumber internet.

Buku teks juga harus dapat meningkatkan minat siswa dalam belajar dan membaca sehingga memperoleh pengetahuan. Peranan bahan ajar menempati tiga posisi penting. Ketiga posisi itu adalah sebagai representase sajian guru, sebagai sarana pencapaian standar kompetensi, kompetensi dasar, standar kompetensi lulusan, dan sebagai pengoptimalan pelayanan terhadap peserta didik. (Djono, 2013:20).

Selain itu bahan ajar dapat berperan dalam beberapa aspek sebagaimana menurut Cunningswort (1995:7) ada tujuh peranan bahan ajar antara lain ; (1) sumber yaitu bahan presentasi pengajaran secara lisan atau tertulis; (2) sumber aktivitas dan interaksi komunikatif bagi peserta didik; (3) sumber referensi tata bahasa, kosa kata, pelafalan, dan sebagainya ; (4) sumber pembangkit gagasan aktivitas bahasa dalam kelas; (5) silabus atau merefleksikan tujuantujuan pembelajaran yang telah ditentukan; (6) sumber pembelajaran mandiri atau tugas mandiri; dan (7) sarana pembantu menstimulasi kepercayaan diri, bagi guru yang belum berpengalaman.

Pendidikan dilihat secara sosial budaya mengacu pada hubungan antarindividu dalam suatu lingkungan atau masyarakat. Demikian pula, budaya yang berkembang dalam masyarakat sangat berperan dalam proses pembelajaran (Suryana \& Rusdiana, 2015: 73). Nilai-nilai kearifan lokal yang dapat diangkat dalam pengembangan bahan ajar ini adalah salah satunya kearifan lokal yang terdapat di Kalimantan Barat dimana masyarakatnya hidup dalam beragam budaya serta kaya akan kearifan lokal. Salah satunya adalah Tradisi Saprahan. Tradisi Saprahan merupakan bentuk nyata akulturasi antara budaya lokal dan budaya Islam di Kalimantan Barat, khususnya pada masyarakat Pontianak. Tradisi saprahan ini adalah sebuah jamuan makan yang 
melibatkan banyak orang yang duduk didalam satu barisan/kelompok dan saling berhadapan saat menikmati hidangan yang disajikan. Tradisi saprahan lazimnya diadakan pada acra-acara pernikahan maupun acara-acara perayaan adat lainnya.

Berdasarkan pemaparan diatas, maka dilakukan penelitian pengembangan bahan ajar dengan tujuan menghasilkan bahan ajar berbasis literasi digital nilai-nilai kearifan lokal pada tradisi saprahan di Pontianak. Bahan ajar ini digunakan sebagai salah satu sumber dalam mempelajari sejarah lokal yang berkaitan dengan kebudayaan di Kalimantan Barat khususnya Pontianak.

\section{METODE}

Metode penelitian dalam penelitian ini menggunakan metode penelitian kualitatif. Jenis penelitian dalam penelitian ini adalah penelitian deskriptif. Menurut Best penelitian deskriptif merupakan metode penelitian yang berusaha menggambarkan dan menginterpretasikan objek sesuai dengan apa adanya (dalam Sukardi, 2003:157). Penelitian dilakukan di sekolah SMA dan SMK Negeri di Kalimantan Barat. Pengambilan data dalam penelitian ini dilakukan di SMA Negeri 1 Pontianak, SMA Negeri 8 Pontianak, SMA Negeri 4 Pontianak, SMA Negeri 1 Nanga Taman, dan SMK Negeri 1 Nanga Pinoh

\section{HASIL DAN PEMBAHASAN}

Hasil observasi menunjukkan kegiatan pembelajaran sejarah di ketiga sekolah tersebut sudah mengacu pada kurikulum 2013. Pembelajaran sejarah sendiri sudah banyak mengalami inovasi baik dari segi proses pelaksanaan maupun dari sarana serta fasilitas yang digunakan. Peneliti melihat sudah banyak kemajuan pada proses penyampaian materi sejarahnya, guru sudah mulai melirik sejarah lokal sebagai salah satu materi dasar yang diajarkan pada siswa. Tidak hanya itu, beberapa sekolah juga sudah menerapkan pembelajaran berbasis situs. Walaupun demikian, beberapa guru mengeluhkan kurangnya sumber literasi sejarah sebagai bahan ajar bagi mereka.

Kondisi bahan ajar pada sekolah sampel berdasarkan hasil observasi masih kurang memadai. Guru kebanyakan menggunakan bahan ajar dari buku paket yang juga dikombinasikan dengan buku-buku bacaan sejarah umum. Namun, masih banyak juga materi yang hanya mengandalkan buku paket sebagai bahan ajar. Kekurangan bahan ajar pun dirasakan guru pada saat ingin menyelipkan materi tentang sejarah lokal di kelas. Minimnya bahan ajar yang memuat sejarah lokal membuat guru kesulitan dalam menyajikan materinya di kelas. Keberadaan sejarah lokal dianggap penting karena menghadirkan pembelajaran yang kontekstual karena dekat dengan kehidupan peserta didik. Berdasarkan hasil wawancara tersebut, peneliti menyimpulkan butuh adanya inovasi dalam bahan ajar. 
Pada proses pembelajaran, bahan ajar berupa teks digunakan dalam berbagai cara, misalnya buku teks membaca berbasis pembentukan karakter. Dalam menggunakan buku teks digunakan berbagai cara untuk meningkatkan keterampilan. Menyangkut karakter tersebut maka serangkaian buku teks dirancang sebaik mungkin. Salah satu cara alternatif untuk mensinergikan antra proses pendidikan dengan budaya lokal adalah dengan pengembangan bahan ajar berbasis nilai-nilai karakter berdasarkan nilai-nilai kearifan lokal. Pengembangan bahan ajar berbasis nilai -nilai kearifan lokal ini bisa dimasukkan dalam berbagai mata pelajaran. Bahan ajar berbasis nilai-nilai kearifan lokal ini dirasa perlu karena berkaitan dengan nilai-nilai karakter yang merupakan komponen yang dirancang untuk peserta didik guna membentuknya menjadi manusia yang memiliki kepribadian, watak, sikap, dan jati diri yang baik.

Nilai-nilai kearifan lokal yang dapat diangkat dalam pengembangan bahan ajar ini adalah salah satunya kearifan lokal yang terdapat di Kalimantan Barat dimana masyarakatnya hidup dalam beragam budaya serta kaya akan kearifan lokal. Salah satunya adalah Tradisi Saprahan. Tradisi Saprahan merupakan bentuk nyata akulturasi antara budaya lokal dan budaya Islam di Kalimantan Barat, khususnya pada masyarakat Pontianak. Tradisi saprahan ini adalah sebuah jamuan makan yang melibatkan banyak orang yang duduk didalam satu barisan/kelompok dan saling berhadapan saat menikmati hidangan yang disajikan. Tradisi saprahan lazimnya diadakan pada acra-acara pernikahan maupun acara-acara perayaan adat lainnya.

Tradisi saprahan ini menggambarkan kebersamaan, sopan santun, menghargai yang dituakan, serta memperat tali persaudaraan diantara masyarakat. Namun, dewasa ini para generasi muda banyak yang masih belum memahami bahkan beberapa dari mereka belum mengetahui makna yang terkandung pada pelaksanaan tradisi saprahan ini. Banyak dari kita pun tidak menyadari ada nilai-nilai kearifan lokal yang dapat dilestarikan untuk membentuk karakter yang sadar akan budayanya. Adapun nilai-nilai kearifan lokal dalam tradisi saprahan antara lain nilai religius, nilai saling menghargai, nilai peduli sosial dan lingkungan, nilai toleransi , dan nilai komunikatif. Penting bagi siswa selaku generasi milineal mempelajari tradisi saprahan ini agar tradisi ini tidak hanya sekedar perayaan adat biasa, namun bentuk pendidikan karakter yang terintegrasi dengan kehidupan terdekat siswa.

\section{KESIMPULAN}

Kondisi bahan ajar pada sekolah sampel berdasarkan hasil observasi masih kurang memadai. Guru kebanyakan menggunakan bahan ajar dari buku paket yang juga dikombinasikan dengan buku-buku bacaan sejarah umum. Namun, masih banyak juga materi yang hanya mengandalkan buku paket sebagai bahan ajar. Kekurangan bahan ajar pun dirasakan guru pada saat ingin menyelipkan materi tentang sejarah lokal di kelas. Minimnya bahan ajar yang memuat sejarah lokal membuat guru kesulitan dalam menyajikan materinya di kelas. Keberadaan sejarah 
lokal dianggap penting karena menghadirkan pembelajaran yang kontekstual karena dekat dengan kehidupan peserta didik. Berdasarkan hasil wawancara tersebut, peneliti menyimpulkan butuh adanya inovasi dalam bahan ajar. Keberadaan bahan ajar ini penting dalam pembelajaran sejarah, sebagai salah satu implementasi dalam pendidikan karakter.

\section{UCAPAN TERIMA KASIH}

Penelitian ini didanai oleh hibah PNBP FKIP Universitas Tanjungpura. Peneliti sangat berterima kasih kepada sekolah-sekolah sampel yang sudah ikut memberikan sumbangan ide terhadap pelaksanaan dan keberlanjutan penelitian ini.

\section{REFERENCES / REFERENSI}

Azwar, S. 2012. Tes Prestasi: Fungsi Pengembangan Pengukuran Prestasi Belajar Edisi ke-2. Yogyakarta: Pustaka Pelajar.

Branch, R.M. 2009. Instructional Design: The ADDIE Approach. New York: Springer.

Cunninggsworth, A. 1995. Evaluating and Selecting EFL Teaching Materials. Oxford: Heinemann

Darmadi, H. 2010. Kemampuan Dasar Mengajar. Bandung:Alfabeta

Depdiknas, 2008. Pembelajaran Tuntas, Jakarta, Direktorat Pembinaan Sekolah Menengah Atas, Dikdasmen.

Dick \& Carey. 2009. The systematic design of instruction. New Jersey: Pearson

Djono.2013. Bimbingan dan Konseling Belajar. Surakarta: UNS Press

Emzir. 2012. Metodologi Penelitian Pendidikan: Kuantitatif \& Kualitatif. Jakarta: Rajawali Press.

Hamalik, 0.2013. Proses belajar mengajar. Jakarta: PT Bumi Akasara

Jannah, U. 2012. Menelusuri Sejarah Asal Mula Balikpapan Melalui Perayaan Erau Balik Delapan Sebuah Kajian Budaya Dan Folkor. Jurnal Premiere Educandum (JPE) P-ISSN : 2088-5350

Kartodirdjo, S.1992. Pendekatan Ilmu Sosial dalam Metodologi Penelitian Sejarah. Jakarta: PT Gramedia Pustaka Utama

Kurniawati,T. 2014. Buku Ajar Kependudukan dan Pelayanan KB. Jakarta: EGC

Mukkarromah, N. 2015. Pola Komunikasi Interpersonal Dalam Tradisi Erau di Kutai Kertanegara. Skripsi: Universitas Islam Negeri Sunan Kalijaga Yogyakarta

Richards, J.C. 2001. Curriculum Development in Language Teaching. Cambridge UK: Cambridge University Press

Romiszowski, A.J.1986. Producing Instructional System. Kogan Page: Nichols Publishing Company

Sani,Y.M. 2012. Erau: Ritual Politik dan Kekuasaan. Jurnal Al-Qalam. Vol.18.No 2 
Sartini. 2004. Menggali Kearifan Lokal Nusantara Sebuah Kajian Filsafat. Dalam Jurnal Filsafat (Internet). Dapat diunduh dari http://www.search-document.com/pdf/1/kajiankearifan-lokal-masyarakat-dalam-pengelolaan-sumberdaya-alam-dan-lingkungan.html

Sedyawati, E. 2012. Budaya Indonesia: Kajian Arkeologi Seni dan Sejarah. Jakarta: Rajawali Press

Soebadio, H. 1986. Kepribadian Budaya Bangsa Dalam Ayat Rohaedi, Kepribadian Budaya Bangsa (Local Genius). Jakarta: Dunia Pustaka Jaya

Sudjana, N. 2009. Dasar-dasar proses belajar mengajar. Jakarta: Sinar Baru Algesindo

Sugiyono. 2009. Metode Penelitian Pendidikan: Pendekatan Kuantitatif, Kualitatif, dan R\&D. Bandung: Alfabeta.

Sukmadinata, N.S. 2013. Metode Penelitian Pendidikan. Bandung: Remaja Rosda Karya.

Suryana, Y. \& Rusdiana. 2015. Pendidikan Multikultural. Bandung: Pustaka Setia

Susanto, A. 2014. Teori Belajar dan Pembelajaran di Sekolah Dasar. Jakarta: Kencana Prenadamedia Grup 